\author{
Ana Došen \\ Logopedsko-rehabilitacijski centar ABC, Zagreb
}

\section{Traumatsko oštećenje mozga - zašto je logoped potreban?}

\author{
Traumatic brain injury - why is speech \\ language pathologist required?
}

\begin{abstract}
SAŽETAK
Traumatsko oštećenje mozga podrazumijeva ozljedu moždanog tkiva uzrokovanu fizičkom silom ili nasilnim pomicanjem glave. Posljedično se mogu javiti fizičke, kognitivne, komunikacijske i bihevioralne teškoće koje narušavaju svakodnevno funkcioniranje osobe. Za rehabilitaciju osoba s traumatskim oštećenjem mozga odgovoran je multidisciplinarni tim, u kojem važnu ulogu ima i logoped. Osobe s traumatskim oštećenjem mozga imaju komunikacijskih teškoća, uglavnom kao rezultat narušenih kognitivnih funkcija (pažnje, izvršne funkcije, pamćenja). Mogu imati teškoća u svim jezičnim sastavnicama, a najviše u uporabi jezika, tj. pragmatici. Mogući su govorni poremećaji, najčešće dizartrija, poremećaji gutanja i hranjenja. Cilj je rada prikazati moguće kognitivno-komunikacijske, jezične i govorne teškoće uzrokovane traumatskim oštećenjem mozga i istaknuti važnost i potrebu logopeda u rehabilitaciji takve patologije. Intervencija logopeda počinje kada su sve vitalne funkcije stabilne, a planiranje intervencije oslanja se na principe neuroplastičnosti mozga, tj. sposobnost mozga da se mijenja i reorganizira radi bolje prilagodbe novim situacijama.
\end{abstract}

\begin{abstract}
Traumatic brain injury involves injury to brain tissue caused by physical force or violent movement of the head. Person's daily functioning may be disrupted by physical, cognitive, communication and behavioral difficulties. The rehabilitation of individuals with traumatic brain injury must have a multidisciplinary team in which a speech-language pathologist has an important role. Individuals with traumatic brain injury have communication difficulties that are mainly the result of impaired cognitive functions (attention span, executive functions, memory). They may have difficulties in all language components, but the most prominent are the difficulties in language use, i.e. pragmatics. Dysarthria is the most common speech disorder after traumatic brain injury. Individulas with traumatic brain injury may also have dysphagia. The aim of this paper is to present possible cognitive-communication, language and speech difficulties caused by traumatic brain injury in order to emphasize the importance and need of the speech-language pathologist in the rehabilitation of such pathology. The speech-language pathologist's intervention begins when all vital functions are stable, and the planning of the intervetion relies on the principles of brain neuroplasticity, i.e. brain's ability to change and reorganize in order to adapt better in new situations.
\end{abstract}

Ključne riječi: logoped traumatsko oštećenje mozga kognitivnokomunikacijske teškoće pragmatičke teškoće neuroplastičnost

Keywords: speech and language pathologist traumatic brain injury cognitivecommunication difficulties pragmatic difficulties neuroplasticity 


\section{UVOD}

Traumatsko oštećenje mozga nastaje kada neka vanjska sila djeluje na glavu dovoljno jako da se mozak pomakne unutar lubanje ili dolazi do frakture lubanjskih kostiju, čime se mozak direktno oštećuje (Graham, McIntosh, Maxwell i Nicoll, 2000). Većina slučajeva traumatskog oštećenja mozga kao posljedicu ima fizičke, komunikacijske, kognitivne i/ili bihevioralne teškoće (Hedge, 2006; Roth i Worthington, 2016). U početku su najizraženiji neurofiziološki simptomi (Hegde i Freed, 2017): izmijenjeno stanje svijesti - od omamljenog stanja do kome, glavobolja, zamagljen vid, umor, letargija, napadaji, nemir, uznemirenost, nedostatak motoričke koordinacije, vrtoglavica, tinitus, mučnina, povraćanje, omamljen pogled i poremećaj spavanja. S obzirom na to da se traumatsko oštećenje mozga može javiti u bilo kojoj dobi, s različitim mjestom i opsegom, ne postoji tipično ili atipično oštećenje, ali postoje kognitivne, komunikacijske i bihevioralne posljedice koje su češće primijećene kod osoba s traumatskim oštećenjem mozga. Shipley i McAfee (2021) navode da su to teškoće pažnje, pamćenja, jezične teškoće, dezorijentacija u vremenu prostoru, loše organizacijske vještine, teškoće rezoniranja, smanjena vještina pisanja i crtanja, anomija, nemir, razdražljivost, distrakcija, visoka razina frustracije i anksioznosti, nekonzistentni odgovori, poremećaj okusa i mirisa, loše vještine prosuđivanja, loša kontrola emocija, poricanje teškoća i loša briga o sebi. Davis (2014) ističe kognitivne teškoće - pažnje, pamćenja i izvršnih funkcija kod osoba $\mathrm{s}$ traumatskim oštećenjem mozga, zatim promjene u osobnosti i ponašanju kojih nisu svjesni, teškoće u jezičnoj proizvodnji i razumijevanju, teškoće razumijevanja i proizvodnje diskursa. Moguće su teškoće gutanja i hranjenja (Hegde, 2006; Hegde i Feed, 2017). Navedene teškoće upućuju na važnost logopeda - kao člana multidisciplinarnog tima u rehabilitaciji osoba s traumatskim oštećenjem mozga. Cilj rada je prikazati kognitivnokomunikacijske, jezične i govorne teškoće uzrokovane traumatskim oštećenjem mozga, te istaknuti važnost $i$ potrebu logopeda u rehabilitaciji takve patologije.

\section{Komunikacija, jezik, govor}

Čovjekov život nezamisliv je bez komunikacije. Komunikacijom osobe utječu jedna na drugu na kognitivnoj razini, tj. međusobnim izmjenama informacija i ideja mijenjaju svijest i ponašanje (Ljubešić i Cepanec, 2012). Prema Lasswellovu modelu komunikacije, taj čin podrazumijeva davanje odgovora na pitanja tko kaže što, kojim sredstvima, kome i s kakvim djelovanjem (Lasswell, 1948, navedeno u Lasswell, 2007). Riječ je o interpersonalnoj komunikaciji koju treba razlikovati od, primjerice, medijske, novinarske $i$ političke komunikacije. Interpersonalna komunikacija može biti verbalna i neverbalna. Verbalna komunikacija su izgovorene riječi, dok neverbalnu komunikaciju čine vizualne i vokalne (paralingvističke) komponente (King, 1979). Prema tome, razgovor se sastoji od izgovorenih riječi i popratnih, neizgovorenih poruka poput facijalne ekspresije, pokreta i držanja tijela, gesti, kontakta očima, dodira, glasa itd. Komunikacija uključuje i metarazinu razumijevanja u međuljudskim odnosima
(McKenna i Willson, 2008). Komunikacija i jezik nisu sinonimi. Jezik je sustav niza simbola s određenim značenjem i pravila kojima te simbole povezujemo, a razine simbola i pravila nazivaju se jezične sastavnice (Hržica i Peretić, 2015). Jezične sastavnice su: fonologija, morfologija, sintaksa, semantika i pragmatika. Jezik se ostvaruje slušanjem i čitanjem (receptivni jezik), govorenjem i pisanjem (ekspresivni jezik), to su četiri jezične djelatnosti. Jedna od mogućih realizacija jezika je govor. Prema tome, komunikacija, jezik i govor različiti su pojmovi, njihova procjena podrazumijeva promatranje različitih elemenata. Dijagnostika i terapija u području verbalne i neverbalne komunikacije, jezika i govora posao je logopeda. Uz to, logoped je stručnjak osposobljen za rad u području poremećaja glasa, poremećaja gutanja i hranjenja.

\section{Kognitivno-komunikacijske teškoće}

Kao posljedica oštećenja frontalnih regija zbog traumatskog oštećenja mozga javljaju se teškoće pažnje i izvršnih funkcija, dok oštećenja temporalnih regija dovode do teškoća pamćenja (Davis, 2014). Jedan od najčešćih modela procjene pažnje u kliničkoj praksi model je Sohlberga i Mateera (1989), koji dijeli pažnju na fokusiranu, trajnu, selektivnu, naizmjeničnu i podijeljenu. Model se temelji na oporavku pažnje kod osoba koje su se probudile iz kome. Fokusirana pažnja odnosi se na sposobnost prikladnog reagiranja na vizualne, slušne i taktilne podražaje. Trajna pažnja odnosi se na dosljedno održavanje pažnje tijekom kontinuiranih i ponavljajućih aktivnosti. Selektivna pažnja odnosi se na održavanje pažnje unatoč ometajućim podražajima. Izmjenična pažnja odnosi se na sposobnost prebacivanja pažnje između različitih zadataka. I posljednja, podijeljena pažnja, odnosi se na sposobnost simultanog odgovaranja na više zadataka ili zahtjeva. Uz teškoće pažnje, mogu se javiti teškoće izvršnih funkcija. Izvršne funkcije obuhvaćaju niz međusobno povezanih procesa potrebnih za svrhovito, cilju usmjereno ponašanje. Promjene u izvedbi na zadacima izvršnih funkcija od dječje do odrasle dobi povezane su s promjenom u građi prednje čeone moždane kore (Šimleša i Cepanec, 2008). Anderson (2002) predlaže model izvršnih funkcija i njihove četiri različite domene u međusobnoj interakciji: kontrolu pažnje, obradu informacija, kognitivnu fleksibilnost i postavljanje ciljeva. Kontrola pažnje odnosi se na selektivnu pažnju, samoregulaciju, samonadziranje i inhibiciju. Obrada informacija odnosi se na učinkovitost, fluentnost i brzinu obrade. Kognitivna fleksibilnost odnosi se na podijeljenu pažnju, radnu memoriju, konceptualni prijenos $\mathrm{i}$ iskorištavanje povratnih informacija. Postavljanje ciljeva odnosi se na inicijaciju, konceptualno rezoniranje, planiranje i organizaciju strategija. Autor modela navodi da će narušenost u kontroli pažnje dovesti do impulzivnog ponašanja, smanjenja samokontrole, neuspješnog ispunjavanja zadataka, činjenja jednakih pogrešaka koje se neuspješno ispravljaju i davanja neprimjerenog odgovora. Nadalje, narušenost u obradi informacija dovest će do smanjenih i odgođenih odgovora, sporijeg vremena reagiranja i neodlučnosti, dok će narušenost u postavljanju ciljeva rezultirati lošom sposobnošću rješavanja problema, neorganiziranošću, poteškoćama u planiranju i razvoju učinkovitih strategija, te teškoćama oslanjanja na prethodno naučene strategije. 
Kognitivno nefleksibilni pojedinci imat će teškoća s prilagodbom na nove zahtjeve i promijenjene aktivnosti. Osobe nakon traumatskog oštećenja mozga mogu imati teškoća s pamćenjem, što se uglavnom veže za temporalne regije. Poznata je podjela na dugoročno i kratkoročno pamćenje. Kada su teškoće s pamćenjem uzrokovane ozljedom temporalnog režnja, prvenstveno se misli na dugoročno pamćenje, dok se kratkoročno pamćenje veže za frontalni režanj (Baddeley i Warrington, 1970). Osim toga, dugoročno i kratkoročno pamćenje razlikuju se u kapacitetu i vremenu zadržavanja informacija (Cowan, 2008). Dugoročno pamćenje, u odnosu na kratkoročno, ima neograničen kapacitet. Kada se kratkoročno pamćenje primjenjuje na kognitivne zadatke, tada preuzima ulogu radnog pamćenja. Radno pamćenje definira se kao višekomponentni sustav koji zadržava i manipulira informacijama u kratkoročnom pamćenju (Cowan, 2008). Radno pamćenje uvrštava se u izvršne funkcije (Anderson, 2002). Gubitak dugoročnog pamćenja prikazuju se u obliku retrogradne i anterogradne amnezije (Davis, 2014; Hegde, 2006). Retrogradna amnezija podrazumijeva gubitak sjećanja na događaje prije ozljede, dok anterogradna podrazumijeva zaboravljanje događaja nakon ozljede. Moguće su prospektivne, neposredne i proceduralne teškoće pamćenja (Hedge i Freed, 2017). Retrospektivno pamćenje odnosi se na pamćenje riječi, osoba i događaja u prošlosti, a prospektivno pamćenje odnosi se na pamćenje budućih događaja, tj. da u pravo vrijeme i na pravom mjestu osoba postane svjesna prethodno osmišljenog plana (Greene, 2008). Primjerice, teškoće prospektivnog pamćenja mogu uzrokovati zaboravljanje termina kod liječnika, zaboravljanje odlaska u trgovinu nakon posla, zaboravljanje redovitog uzimanja lijekova i sl. Neposredno pamćenje odnosi se na sjećanje upravo proživljenih događaja, što podrazumijeva prethodno opisano kratkoročno pamćenje. Proceduralno pamćenje (implicitno) i deklarativno pamćenje (eksplicitno) dijelovi su dugoročnog pamćenja. Deklarativno pamćenje odnosi se na prisjećanje činjenica i događaja, lakše se verbalizira od proceduralnog pamćenja koje se odnosi na izvedbu određenih vrsta zadataka (Sandrini i Cohen, 2014). Teškoće proceduralnog pamćenja kod osoba s traumatskim oštećenjem mozga mogu rezultirati teškoćom izvođenja zadataka poput vožnje automobila, brijanja, kuhanja i sl. Logoped bi trebao poznavati i razumjeti kognitivne teškoće osoba s traumatskim oštećenjem mozga jer su one u pozadini narušene komunikacije. Važno je napomenuti da opsežne procjene kognitivnih funkcija, pomoću standardiziranih instrumenata, provodi psiholog. Čitajući psihološke nalaze, logoped treba razumjeti na koji način narušene kognitivne funkcije utječu na komunikaciju osoba s traumatskim oštećenjem mozga.

\section{Komunikacijske, jezične i govorne teškoće}

Komunikacijske teškoće uzrokovane traumatskim oštećenjem mozga razlikuju se od teškoća uzrokovanih cerebrovaskularnim ozljedama. Komunikacijske teškoće uzrokovane traumatskim oštećenjem mozga uglavnom su rezultat kombinacije kognitivnih i jezičnih oštećenja (Togher, 2010). Razlika između afazije i komunikacijskih teškoća nakon traumatskog oštećenja mozga počinje se primjećivati tek 1980. godina. Holland (1982, prema Togher,
McDonald i Code, 1999) zaključuje da su jezične teškoće uzrokovane traumatskim oštećenjem mozga sekundarna posljedica kognitivnih teškoća. Nadalje, Braun i Baribeau (1987, prema Togher i sur., 1999) ističu teškoće neverbalne komunikacije, što upućuje na još jednu razliku između komunikacijskih teškoća nakon traumatskog oštećenja mozga i afazije. Za uspješnu međuljudsku komunikaciju potrebno je više od jezika. Zato komunikacija predstavlja temelj na kojem se gradi jezik. Kod osoba s traumatskim oštećenjem mozga dominantno su izražene teškoće u socijalnoj komunikaciji (Togher, 2010). Vodeći se prijašnjim radovima, American Speech-Language-Hearing Association prikazuje socijalnu komunikaciju kao spoj socijalne interakcije, socijalne kognicije (teorija uma, emocionalna kompetencija, izvršne funkcije), pragmatike i obrade jezika. Kod osoba s traumatskim oštećenjem mozga sve jezične sastavnice mogu biti narušene, a najveće teškoće izražene su u pragmatici, tj. uporabi jezika (Zimmermann, Gindri, Rosa de Oliveira i Paz Fonseca, 2011). ASHA pragmatiku objašnjava kroz neverbalnu komunikaciju (npr. govor tijela, geste, facijalna ekspresija, kontakt očima, izmjena pogleda) i verbalnu komunikaciju (npr. govorni činovi, prozodija, Griceove maksime, diskurs). Neverbalna komunikacija može biti izrazito narušena kod osoba s traumatskim oštećenjem mozga, npr. facijalna ekspresija, kontakt očima, izmjena pogleda i drugi neverbalni znakovi mogu izostati u komunikaciji. Razumijevanje neverbalnih znakova, kao i njihova proizvodnja, može izostati (Hegde i Freed, 2017; Hegde, 2006). Prema teoriji govornih činova (Austin, 1975) - jednoj od najpoznatijih teorija unutar pragmatike - svaki govorni čin ima formu (lokucija), namjeru (ilokucija) i učinak (perlokucija). Forma se može mijenjati ovisno o kontekstu, dok namjera ostaje ista. Teškoće u izvršnim funkcijama mogu otežati prilagodbu forme novim kontekstima i/ili razumijevanje namjera sugovornika. Teškoće auditivnog razumijevanja koje dovode do odgođenog ili neprikladnog odgovora, uglavnom se odnose na teškoće razumijevanja složenih i apstraktnih izjava (npr. ironija, metafore) (Hegde, 2006). Kod osoba s traumatskim oštećenjem mozga vrlo često se analizira diskurs, skup međusobno povezanih rečenica. Definira se kao prirodan i dinamičan oblik komunikacije, koji zahtijeva aktivaciju i interakciju više međusobno povezanih kognitivnih i jezičnih podsustava (Wright i Capilouto, 2012), upravo zbog toga očekivane su teškoće u diskursu kod osoba s traumatskim oštećenjem mozga. Teškoće s diskursom mogu se pojaviti na razini mikrostrukture, ali češće na razini makrostrukture (Coelho i sur., 2013). Makrostruktura podrazumijeva višerazinsku jezičnu organizaciju sadržaja u rečenicama za koherentni i potpuni diskurs, dok mikrostruktura podrazumijeva izbor riječi i sintaktičku organizaciju unutar rečenice (Coelho i sur., 2013). Često zbog poteškoća u odražavanju pažnje te vanjskih i unutarnjih distrakcija, osobama s traumatskim oštećenjem mozga narušen je protok misli, što otežava održavanje teme razgovora i uzrokuje skakanje s jedne teme na drugu, nekoherentnost, konfabulacije, cirkumlokucije, teškoće izvlačenja bitnih informacija i zaključivanje na temelju ograničenog broja informacija (Hegde 2006; Hegde i Freed, 2017; McKenna i Wilson, 2008). Osim toga, vidljive su teškoće u spontanom započinjanju razgovora, konverzacijskim izmjenama i odabiru prikladnih tema (Hegde 2006; Hegde i Freed, 2017). Takve teškoće često se javljaju zbog problema sa samokontrolom (McKenna i 
Wilson, 2008). Socijalna neprimjerenost poput impulzivnosti, manjka empatije i egocentričnosti, mogu uzrokovati teškoće u konverzacijskim izmjenama, nerazumijevanje i nepokazivanje interesa za tuđe potrebe, a isto tako, reducirani su ili potpuno odsutni pokušaji popravljanja pogrešaka u konverzaciji (McKenna i Willson, 2008). Uspoređujući narativni diskurs urednih govornika i govornika s traumatskim oštećenjem mozga uočavaju se razlike. Priče govornika s traumatskim oštećenjem mozga necjelovite su i s nepotpunim epizodama (Power i sur., 2019). Osim u narativnom diskursu, teškoće se primjećuju u konverzaciji. Analizirajući konverzaciju kod osoba s težim traumatskim oštećenjem mozga, Rousseaux, Verigneaux i Kozlowski (2010) uočili su smanjeno sudjelovanje u konverzaciji, teškoće u socijalnoj interakciji, smanjene verbalne i neverbalne poticaje. Autori su opisali produkciju kao reduciranu i teško razumljivu, ali bez gramatičkih pogrešaka. Istaknule su se pragmatičke teškoće koje su se očitovale u teškoćama odgovaranja na otvorena pitanja, teškoćama uvođenja novih informacija i novih tema, nelogičnoj organizaciji diskursa, neprilagodbi informacija sugovornikovu znanju i teškoćama upravljanja i prikladnog odgovaranja na povratne informacije. Primijećene su teškoće neverbalne komunikacije, tj. nerazumijevanje gesti 1 narušena prozodija. Kod osoba s traumatskim oštećenjem mozga, u početnoj fazi oporavka, mogu se primijetiti teškoće u fonologiji, morfologiji, sintaksi i semantici, koje se uglavnom potpuno oporave $\mathrm{s}$ vremenom (Weismer $\mathrm{i}$ Brown, 2021). Teškoće imenovanja nisu izražene kao kod osoba s afazijom, ali mogu biti prisutne, često zbog pogrešne vidne percepcije ili impulzivnih reakcija (Hegde, 2006). Uz teškoće imenovanja, navodi se prisustvo perseveracija u verbalnim odgovorima i reducirana tečnost govora koja može biti uzrokovana reduciranom pažnjom. Opisane teškoće u verbalnom jeziku mogu se primijeniti i na pisani jezik. Osobe s traumatskim oštećenjem mozga mogu imati teškoća u razumijevanju i pisanju dužeg, povezanog teksta (Hegde, 2006, Hegde i Freed, 2017). Ovisno o opsegu ozljede, govorne teškoće mogu biti izraženije od jezičnih teškoća, a najčešće je riječ o spastičnoj dizartriji (Hegde, 2006). Važno je napomenuti da komunikacijske, jezične i govorne teškoće, te ostale moguće teškoće uzrokovane traumatskim oštećenjem mozga ovise o individualnim karakteristikama osobe i prirodi ozlijede.

\section{Logopedska intervencija}

Bolnička medicinska rehabilitacija počinje kada su sve vitalne funkcije stabilne, tj. kada dijagnostički i terapijski postupci u jedinici intenzivnog liječenja više nisu indicirani (Bakran i sur., 2015). Cilj logopedske intervencije poboljšanje je kompetencija u području komunikacije unutar obitelji, u zajednici, socijalnoj komunikaciji, radnoj okolini, u obrazovanju i radi upravljanja informacijama, te komunikacije u svrhu rješavanja problema (MacDonald, 2017). Kod planiranja intervencije uzima se u obzir neuroplastičnost mozga, tj. sposobnost mozga da restrukturira neuronske veze kao odgovor na unutarnje i vanjske podražaje. Kleim i Jones (2008) prikazali su deset principa neuroplastičnosti koji se mogu iskoristiti u logopedskoj terapiji. Principi i njihov opis prikazani su u tablici.
Tablica 1. Principi neuroplastičnosti koji se mogu primijeniti u logopedskoj terapiji osoba s traumatskim oštećenjem mozga (prema Kleim i Jones, 2008).

\begin{tabular}{|c|c|}
\hline Principi & Opis \\
\hline Koristiti ili izgubiti & $\begin{array}{l}\text { Nekorištenje specifičnih kognitivnih } \\
\text { funkcija može dovesti do } \\
\text { funkcionalne degeneracije. }\end{array}$ \\
\hline Koristiti i poboljšati & $\begin{array}{l}\text { Zadaci koji aktiviraju određene } \\
\text { kognitivne funkcije mogu dovesti do } \\
\text { poboljšanja tih funkcija. }\end{array}$ \\
\hline Specifičnost & $\begin{array}{l}\text { Proces učenja nakon oštećenja } \\
\text { mozga razlikuje se od tipičnog } \\
\text { učenja, zbog toga su neuronske } \\
\text { promjene ograničene i strogo vezane } \\
\text { za ciljani zadatak. }\end{array}$ \\
\hline Ponavljanje je važno & $\begin{array}{l}\text { Ponavljanje je važno kako bi se } \\
\text { uspostavile i održale bihevioralne i } \\
\text { neurološke promjene. }\end{array}$ \\
\hline Intenzitet je važan & $\begin{array}{l}\text { Učestala terapija dovodi do boljih } \\
\text { ishoda. }\end{array}$ \\
\hline Vrijeme je važno & $\begin{array}{l}\text { Različiti oblici neuroplastičnosti } \\
\text { javljaju se u različito vrijeme tijekom } \\
\text { rehabilitacije. Rana intervencija može } \\
\text { usmjeravati neuronsko } \\
\text { restrukturiranje koje je već u tijeku. }\end{array}$ \\
\hline Izraženost je važna & $\begin{array}{l}\text { Aktivnosti moraju biti izražene i } \\
\text { relevantne. Manjak motivacije može } \\
\text { utjecati na izraženost i posljedično } \\
\text { loš ishod. }\end{array}$ \\
\hline Dob je važna & $\begin{array}{l}\text { Plastičnost izazvana terapijom brže i } \\
\text { lakše se javlja kod mlađih osoba. }\end{array}$ \\
\hline Prijenos & $\begin{array}{l}\text { Neurološke i bihevioralne promjene } \\
\text { kao odgovor na jedan oblik terapije } \\
\text { mogu olakšati usvajanje sličnih } \\
\text { ponašanja. }\end{array}$ \\
\hline Interferencija & $\begin{array}{l}\text { Neurološke i bihevioralne promjene } \\
\text { kao odgovor na jedan oblik terapije } \\
\text { mogu ometati usvajanje drugih } \\
\text { ponašanja. }\end{array}$ \\
\hline
\end{tabular}

Cilj je logopedske rehabilitacije vratiti pacijenta na razinu njegovog prethodnog funkcioniranja što je više moguće te poboljšati kvalitetu života. Rehabilitacija se obično sastoji od dvije faze - prva se odvija tijekom bolničkog liječenja, a druga nakon otpusta iz bolnice (Khan, Baguley i Cameron, 2003). Terapijski plan ovisi o težini ozljede, fazi oporavka i individualnih teškoća u pojedinim područjima. Rana logopedska terapija može se odvijati dok je pacijent u komi, izazivanjem općih odgovora na senzornu stimulaciju (Brain Injury Law Center, 2021). Neke od senzornih stimulacija su dodirivanje ruke, glasno govorenje $\mathrm{u}$ uho, stavljanje hrane ispred nosa kako bi pacijent reagirao na miris. Osim taktilnih, auditivnih i olfaktornih stimulacija, upotrebljavaju se gustativne, kinestetičke i vizualne stimulacije, npr. štapići s okusima, pomicanje položaja tijela pacijenta, stimulacija svjetlima i različitim bojama. Ako pacijent ima kanilu, logoped je povremeno mehanički zatvara, 
tj. provjerava sposobnost samostalnog disanja. Također, logoped provodi orofacijalnu masažu, elektrostimulaciju paretičnih mišića i vodi brigu o higijeni usne šupljine pacijenta. Kada se pacijent probudi iz kome i počne odgovarati na stimulacije, terapija se počinje usmjeravati na održavanje koncentracije i pažnje tijekom obavljanja osnovnih aktivnosti, na informiranje pacijenta o tome koji je dan, godina, gdje se nalazi i što se dogodilo (Brain Injury Law Center, 2021). Osim toga, logoped se usmjerava na poboljšanje izvršnih funkcija i socijalnih sposobnosti, što boljem i samostalnijem funkcioniranju osobe u zajednici. Logoped će pomoći osobi da poboljša svoj govor, učinkovitije izrazi svoje misli i ideje, bolje razumije ono što pročita, poboljša pažnju kod obavljanja svakodnevnih aktivnosti, poboljša pamćenje i vještine planiranja, organiziranja i rješavanja problema, poboljša socijalne vještine i nauči samostalno gutati (ASHA). Traumatsko oštećenje mozga može dovesti do trenutnog ili trajnog gubitka govora. U svakom slučaju, potrebno je omogućiti pacijentu korištenje sustava augmentativne $\mathrm{i}$ alternativne komunikacije koji odgovara fazi oporavka, a logoped treba biti kompetentan u njegovoj procjeni i implementaciji (Campbell, Balandin i Togher, 2002).

\section{ZAKLJUČAK}

Logoped je stručnjak osposobljen za rad u području komunikacije, jezika, govora, glasa, gutanja i hranjenja. Važan je član multidisciplinarnog tima u rehabilitaciji osoba s traumatskim oštećenjem mozga jer se osobe s traumatskim oštećenjem mozga suočavaju s teškoćama koje su u području logopedskog rada. Kognitivno-komunikacijske, jezične i govorne teškoće narušavaju njihovo svakodnevno funkcioniranje. Zadaća je logopeda poboljšati svakodnevne komunikacijske sposobnosti osobe i time povećati njegovu samostalnost, sudjelovanje u zajednici i kvalitetu života.

\section{LITERATURA}

1) American Speech-Language-Hearing Association. Components of Social Communication. Preuzeto s https://www.asha.org/practice-portal/clinical-topics/socialcommunication-disorder/components-of-social-

communication/

2) American Speech-Language-Hearing Association. Traumatic Brain Injury (TBI). Preuzeto s https://www.asha.org/public/speech/disorders/traumaticbrain-injury/

3) Anderson, P. (2002). Assessment and Development of Executive Function (EF) During Childhood. Child Neuropsychology, $8(2)$,

71-82. https://doi.org/10.1076/chin.8.2.71.8724

4) Austin, J. L. (1975). How to do things with words (2 $2^{\text {nd }}$ ed.). Cambridge, MA, US: Harvard University Press.

5) Baddeley, A. D., Warrington, E. K. (1970). Amnesia and the distinction between long- and short-term memory. Journal of Verbal Learning and Verbal Behavior, 9(2), 176-189. https://doi.org/10.1016/S0022-5371(70)80048-2

6) Bakran, Ž., Schnurrer-Luke-Vrbanić, T., Kadojić, M.,
Moslavac, S., Vlak, T. i Grazio, S. (2015). Smjernice u rehabilitaciji bolesnika s traumatskom ozljedom mozga. Fizikalna i rehabilitacijska medicina, 27 (3-4), 270-301. Preuzeto s https://hrcak.srce.hr/163312

7) Brain Injury Law Center (2021). The role of speech therapy in traumatic brain injury. Preuzeto s https://www.brain-injurylaw-center.com/blog/the-role-of-speech-therapy-intraumatic-brain-injury/

8) Campbell L., Balandin, S., Togher, L. (2002). Augmentative and alternative communication use by people with traumatic brain injury: A review. Advances in Speech Language Pathology 4(2), 89-94. http://dx.doi.org/10.1080/14417040210001669311

9) Coelho, C., Lê, K., Mozeiko, J., Hamilton, M., Tyler, E., Krueger, F., \& Grafman, J. (2013). Characterizing discourse deficits following penetrating head injury: A preliminary model. American Journal of Speech-Language Pathology, 22(2), 438-448. https://doi.org/10.1044/1058-0360(2013/120076)

10) Cowan, N. (2008). What are the differences between long-term, short-term, and working memory? Progress in Brain Research, 169, 323-338. https://doi.org/10.1016/S0079-6123(07)00020-9

11) Davis, G. A. (2014). Aphasia and Related CognitiveCommunicative Disorders. Boston, MA, US: Pearson Education, Inc.

12) Graham D. I., McIntosh T. K., Maxwell W. L., Nicoll, J. A. (2000). Recent advances in neurotrauma. Journal of Neuropathology \& Experimental Neurology, 59, 641-651. https://doi.org/10.1093/jnen/59.8.641

13) Greene, E. (2008). Transparent Meta-Analysis of Prospective Memory and Aging. PLoS One, 3(2). https://doi.org/10.1371/journal.pone.0001568

14) Hegde, M. N. (2006). A Coursebook on Aphasia and Other Neurogenic Language Disorders ( $3^{\text {rd }}$ ed.). Clifton Park, NY, US: Thomson Delmar Learning.

15) Hegde, M. N., Freed, D. (2017). Assessment of Communication Disorders in Adults: Resources and Protocols ( $2^{\text {nd }}$ ed.). San Diego, CA, US: Plural Publishing Inc.

16) Hržica, G., Peretić, M. (2015). Što je jezik? U: J. Kuvač Kraljević (ur.) Vodic za prepoznavanje i obrazovanje djece s jezičnim teškoćama (str. 9-25). Zagreb: Edukacijsko-rehabilitacijski fakultet Sveučilišta u Zagrebu.

17) Khan, F., Baguley, I. J., Cameron, I. D. (2003). Rehabilitation after trauatic brain injury. The Medical Journal of Australia, 178(6), 290-295. https://doi.org/10.5694/j.13265377.2003.tb05199.x

18) King, R. G. (1979). Fundamentals of Human Communication. New Jersey, US: MacMillan Publishing Company.

19) Kleim, J. A., Jones, T. A. (2008). Principles of Experience-Dependent Neural Plasticity: Implications for Rehabilitation After Brain Damage. Journal of Speech Language and Hearing Research, 51(1), 2-25. https://doi.org/10.1044/1092-4388(2008/018)

20) Lasswell, H., D. (2007). The structure and function of communication in society. Illetisim kuram ve arastırma dergisi Sayl, 24, 215-228. Preuzeto s https://pdf4pro.com/amp/view/the-structure-andfunction-of-communication-in-society-52b72f.html 21) Ljubešić, M., Cepanec, M. (2012). Rana komunikacija: U čemu je tajna? Logopedija, 3(1), 35-45. Preuzeto s https://hrcak.srce.hr/123819

22) MacDonald, S. (2017). Introducing the model of 
cognitive-communication competence: A model to guide evidence-based communication interventions after brain injury. Brain Injury, 31, 1760-1780. https://doi.org/10.1080/02699052.2017.1379613

23) Power, E., Weir, S., Richardson, J., Fromm, D., Forbes, M., MacWhinney, B., Togher, L. (2019). Patterns of narrative discourse in early recovery following severe Traumaic Brain Injury. Brain Injury, 34, 98-109. https://doi.org/10.1080/02699052.2019.1682192

24) Roth, F. P., Worthington, C. K. (2016). Treatment Resource Manual for speech-language pathology (5th $\mathrm{ed}$.). New York, US: Cengage Learning.

25) Rousseaux, M., Vérigneaux, C., Kozlowski, O. (2010). An analysis of communication in conversation after severe traumatic brain injury. European Journal of Neurology, 17(7), 922-929. https://doi.org/10.1111/j.1468-

1331.2009.02945.x

26) Sandrini, M., Cohen, L. G. (2014). Effects of Brain Stimulation on Declarative and Procedural Memories. U: R. Cohen Kadosh (ur.). The Stimulated Brain: Cognitive Enhancement Using Non-Invasive Brain Stimulation (str. $237-$ 263). London, UK: Elsevier Inc.

27) Shipley, K. G., McAfee, J. G. (2021). Assessment in speech-language pathology: A Resource Manual, Sixth Edition. San Diego, CA, US: Plural Publishing Inc.

28) Sohlberg, M. M., Mateer, C. A. (1989). Introduction to cognitive rehabilitation: theory and practice. New York, US: Guilford Press.

29) Šimleša, S., Cepanec, M. (2008). Razvoj izvršnih funkcija i njihovih neuroloških korelata. Suvremena psibologija, 11 (1), 55-72. Preuzeto s https://hrcak.srce.hr/81398

30) Togher, L. (2010). Cognitive Communication Disorders After Traumatic Brain Injury. U: J. Guendouzi, F. Loncke, M. J. Williams (ur.). The Handbook of Psycholinguistic and Cognitive Processes, Perspectives in Communication Disorders (str. 603-624). London, UK: Informa Ltd Routledge.

31) Togher, L., McDonald, S., Code, C. (1999). Communication problems following traumatic brain injury. U: S. Mc Donald, L. Togher, C. Code (ur.). Communication disorders following traumatic brain injury (str. 1-18). New York, US: Psychology Press.

32) Wright, H. H., Capilouto, G. J. (2012). Considering a multi-level approach to understanding maintenance of global coherence in adults with aphasia. Aphasiology, 26(5), 656-672. https://doi.org/10.1080/02687038.2012.676855

33) Zimmermann, N., Gindri, G., Rosa de Oliveira, C., Paz Fonseca, R. (2011). Pragmatic and executive functions in traumatic brain injury and right brain damage: An exploratory comparative study. Dement Neuropsychol., 5(4), 337-345. https://doi.org/10.1590/S1980

$57642011 \mathrm{DN} 05040013$ 